\title{
Automated urban rainfall-runoff model generation with detailed land cover and flow routing
}

\section{Niemi, Tero}

2019-05

Niemi , T, Kokkonen , T , Sillanpää , N , Setälä , H \& Koivusalo , H 2019 , ' Automated urban rainfall-runoff model generation with detailed land cover and flow routing ' , Journal of Hydrologic Engineering , vol. 24 , no. 5 , 04019011 . https://doi.org/10.1061/(ASCE)HE.1943-5584.0001784

http://hdl.handle.net/10138/308204

https://doi.org/10.1061/(ASCE)HE.1943-5584.0001784

cc_by_nc_nd

acceptedVersion

Downloaded from Helda, University of Helsinki institutional repository.

This is an electronic reprint of the original article.

This reprint may differ from the original in pagination and typographic detail.

Please cite the original version. 


\section{A Aatto University}

This is an electronic reprint of the original article.

This reprint may differ from the original in pagination and typographic detail.

Niemi, Tero; Kokkonen, Teemu; Sillanpää, Nora; Setälä, Heikki; Koivusalo, Harri

\section{Automated Urban Rainfall-Runoff Model Generation with Detailed Land Cover and Flow Routing}

Published in:

JOURNAL OF HYDROLOGIC ENGINEERING

DOI:

10.1061/(ASCE)HE.1943-5584.0001784

Published: 01/05/2019

Document Version

Peer reviewed version

Please cite the original version:

Niemi, T., Kokkonen, T., Sillanpää, N., Setälä, H., \& Koivusalo, H. (2019). Automated Urban Rainfall-Runoff Model Generation with Detailed Land Cover and Flow Routing. JOURNAL OF HYDROLOGIC ENGINEERING, 24(5), [04019011]. https://doi.org/10.1061/(ASCE)HE.1943-5584.0001784

This material is protected by copyright and other intellectual property rights, and duplication or sale of all or part of any of the repository collections is not permitted, except that material may be duplicated by you for your research use or educational purposes in electronic or print form. You must obtain permission for any other use. Electronic or print copies may not be offered, whether for sale or otherwise to anyone who is not an authorised user. 


\section{Automated urban rainfall-runoff model generation with \\ 2 detailed land cover and flow routing}

3

4 Tero J. Niemi, D.Sc. ${ }^{1}$; Teemu Kokkonen, D.Sc. ${ }^{2}$; Nora Sillanpää, D.Sc. ${ }^{3}$; Heikki Setälä,

$5 \quad$ Ph.D. ${ }^{4}$; Harri Koivusalo, D.Sc. ${ }^{5}$

6

$7{ }^{1}$ Postdoctoral Researcher, Department of Built Environment, Aalto University School of 8 Engineering, PO Box 15200, FI-00076 Aalto, Finland (corresponding author). Phone: +358

950562 5427, E-mail: tero.niemi@aalto.fi

$10{ }^{2}$ Senior University Lecturer, Department of Built Environment, Aalto University School of 11 Engineering, PO Box 15200,FI-00076 Aalto, Finland.E-mail: teemu.kokkonen@aalto.fi

$12{ }^{3}$ Postdoctoral Researcher, Department of Built Environment, Aalto University School of 13 Engineering, PO Box 15200, FI-00076 Aalto, Finland. E-mail: nora.sillanpaa@aalto.fi

$14{ }^{4}$ Professor, Faculty of Biological and Environmental Sciences, University of Helsinki, 15 Niemenkatu 73, FI-15140Lahti, Finland.E-mail: heikki.setala@helsinki.fi

$16{ }^{5}$ Professor, Department of Built Environment, Aalto University School of Engineering, PO Box 17 15200, FI-00076 Aalto, Finland.E-mail: harri.koivusalo@aalto.fi 


\section{Abstract}

20 Constructing hydrological models for large urban areas is time consuming and laborious due

21 to the requirements for high-resolution data and fine model detail. An open-source algorithm

22 using adaptive subcatchments is proposed to automate Storm Water Management Model

23 (SWMM) construction. The algorithm merges areas with homogeneous land cover and 24 common outlet into larger subcatchments, while retaining small-scale details where land cover

25 or topography is more heterogeneous. The method was tested on an 85 ha urban catchment in

26 Helsinki, Finland. A model with adaptive subcatchments reproduced the observed discharge at

27 the catchment outlet with high model-performance indices emphasizing the strength of the

28 proposed method. Computation times of the adaptive model were substantially lower than those

29 of a corresponding model with uniformly sized high-resolution subcatchments. Given that

30 high-resolution land cover and topography data are available, the proposed algorithm provides

31 an advanced method for implementing SWMM models automatically even for large urban

32 catchments without substantial manual workload. Simultaneously, the high-resolution land

33 cover details of the catchments can be maintained where they matter the most.

\section{Keywords}

35 SWMM, urban hydrology, stormwater, subcatchment delineation, automation, flow routing 


\section{Introduction}

38 Urban areas are characterized by fragmented, mosaic land cover leading to altered hydrological

39 cycle when compared to natural areas. The changing landscape due to urbanization has impacts

40 on heat balance and evaporation (Whitford et al., 2001; Zhou et al., 2011), snow cover and

41 snowmelt (Bengtsson and Semádeni-Davies, 2011), infiltration and storm runoff generation

42 (Sillanpää and Koivusalo, 2015), and biodiversity (Pauleit et al., 2005) amongst other effects.

43 To understand the hydrology-related processes in urban areas, accurate description and

44 understanding of the land cover spatial configuration is crucial (Fletcher et al., 2013; Salvadore

45 et al., 2015).

The high-resolution description of catchment details is important in urban hydrological models

47 (Cantone and Schmidt, 2009). While for runoff volumes the impact of spatial resolution may be modest or even negligible (Ghosh and Hellweger, 2012; Goldstein et al., 2016; Krebs et al., 2014; Park et al., 2008), the high detail in land cover description is particularly important for accurate simulation of peak flow rates (Elliott et al., 2009; Ghosh and Hellweger, 2012; Krebs et al., 2014). In addition to the increased accuracy of runoff simulations, describing subcatchments in high-resolution as detailed units with homogeneous land cover simplifies the model calibration procedure and narrows parameter ranges (Krebs et al., 2013; Sun et al., 2014).

In urban areas, impervious surfaces contribute the most to urban runoff and understanding their connection to surrounding areas and to the stormwater network is fundamental (Jacobson, 2011; Mejía and Moglen, 2010; Shuster et al., 2005). To accurately represent the flow routing between contributing surfaces in urban hydrological models, flow paths have to be described in detail requiring high-resolution data (Gironás et al., 2010; Rodriguez et al., 2013). The demand for high-resolution spatial descriptions of urban areas is also driven by the assessment 
61 of stormwater management systems, such as low-impact development and nature-based solutions. These are often spatially distributed to individual surfaces or outlets of impervious plots and need to be described in great spatial detail in models (Tuomela et al., 2019).

The US EPA Storm Water Management Model (SWMM) (Rossman, 2015) is a widely used open-source urban hydrological simulation model used for both event-based (e.g., Kong et al., 2017; Niemi et al., 2017) and long-term (e.g., Guan et al., 2015; Peleg et al., 2017; Taka et al., 2017) hydrological assessments in urban areas. Manual construction of high-resolution urban hydrological models, where each contributing surface is individually described (Krebs et al., 2014 , 2013), is only feasible when the studied area is small. For larger areas, such as entire suburbs, automated methods are necessary to keep the task manageable.

Several tools have been proposed to facilitate the task of urban hydrological model construction. Kertesz et al. (2007) developed a tool to compile and transfer subcatchment information from ArcGIS Geographical Information System (GIS) to SWMM. Pina et al. (2011) introduced an open-source tool inp.PINS for both creating SWMM input files directly from GIS and for visualizing SWMM results in GIS, but the tool has since become deprecated. Dongquan et al. (2009) presented a digital elevation model (DEM)-based automated batch process for subcatchment discretization in ArcGIS without accounting for different land covers within subcatchments and tested the results with SWMM. In addition, several commercial modelling packages built around the EPA SWMM computational engine exist (e.g., InfoSWMM and XPSWMM by Innovyze, PCSWMM by Computational Hydraulics

81 International) to aid the modeler e.g., by incorporating superior GIS capabilities over the 82 standard EPA SWMM user interface or by allowing integrated 1D-2D modelling using 2D 83 surface flow descriptions. Nevertheless, even with commercial packages, subcatchment delineation and routing of water between subcatchments and into the stormwater network are 
still largely manual tasks. Clearly, there is still room for improvement as none of the tools facilitate automatic model building while retaining the detailed land cover characteristics of the urban environment.

Easily available, remotely sensed high-resolution data on topography and land cover are abundant (Bates, 2004; French, 2003; Tarolli et al., 2013). This shifts the focus in hydrological modelling from describing the environment in as much detail as possible into such models where simulation times remain feasible (Bates, 2012; Sampson et al., 2012). High-resolution description of land cover and flow paths becomes important in urban environments and requires a modeler to find a balance between necessary level of detail and acceptable computational 94 burden.

Describing a sizeable urban area in high-resolution often results in unfeasibly long simulation times necessitating for a method to aggregate adjacent surfaces into larger computational units. Warsta et al. (2017) proposed an automatic method for building SWMM models in a manner where each DEM/land cover raster cell corresponded to one subcatchment. The method also allowed combining individual grid cells into larger rectangular subcatchments in a rudimentary manner. While this decreased computation times and facilitated application to large urban 101 catchments (Rautiainen, 2016), averaging catchment properties (e.g., elevations) while 102 combining grid cells led to problems with surface runoff routing and to a loss of fine-scale 103 detail in describing land cover and topography.

104 To tackle the challenge of automatically constructing SWMM models in high-resolution while minimizing the computational burden, the main objective of this paper was to propose a new open-source algorithm to automate SWMM model construction. Following the requirements

107 for accurate flow path description and homogenous subcatchment land cover, the proposed 108 algorithm automatically discretizes the studied area in an adaptive manner based on land cover 
109 and flow routing using high-resolution land cover and DEM data. The result is a SWMM model

110 with a minimum number of subcatchments where each subcatchment is covered by a single

111 land cover type.

112 The performance of the new discretization method was demonstrated by comparison against a

113 uniform discretization scheme where each raster cell corresponds to one subcatchment.

114 Simulation results were also compared against field measurements to validate model

115 performance.

\section{2. Materials}

117 The studied Länsi-Pakila catchment (Fig. 1) is an 85 ha urban area in Helsinki, Finland.

118 Helsinki has a boreal climate with a mean annual air temperature of $5.9^{\circ} \mathrm{C}$ and mean annual

119 precipitation of $655 \mathrm{~mm}$, with most of the rainfall falling in late summer and early autumn

120 (Pirinen et al., 2012).

122 The Länsi-Pakila catchment is a medium-density residential area characterized by detached

123 houses. The area is relatively green, with vegetation covering $53.5 \%$, asphalt $27.5 \%$, and roofs

$12413.5 \%$ of the area (Table 1), resulting in a total imperviousness of $43 \%$. The area is prone to 125 stormwater flooding (Raukola, 2012). Länsi-Pakila is subject to urban development and faces 126 a risk of more severe urban flooding in the future unless due attention is paid to stormwater 127 management.

129 An openly available $1 \times 1 \mathrm{~m}^{2}$ DEM from the City of Helsinki was used for catchment 130 delineation. The catchment land cover description was based on the openly available land cover 
131 classification data from the Helsinki Region Environmental Services Authority HSY. As is

132 often the case with urban runoff studies, several site visits were required to complement the

133 scattered stormwater network information available from the network map.

134 Rainfall was measured at the Länsi-Pakila catchment during summer 2017 using three co135 located fully automatic tipping-bucket rain gauges (ECRN-100 High Resolution Rain Gauge)

136 with $0.2 \mathrm{~mm}$ tip size and $1 \mathrm{~min}$ temporal resolution. The gauges were located on top of a low-

137 rise nursing home building to keep them safe from vandalism and to minimize obstruction from 138 the urban surroundings (Fig. 1). Daily air temperature and wind speed data were available from

139 the Finnish Meteorological Institute's weather station in Kumpula, Helsinki, approximately 5

$140 \mathrm{~km}$ south-east from the catchment.

141 Catchment discharge information was obtained by measuring water level and flow velocity at 142 the catchment outfall (Fig. 1) in an $800 \mathrm{~mm}$ concrete pipe using a Starflow Ultrasonic Doppler

143 Instrument Model 6526. The time resolution of the discharge measurements was $1 \mathrm{~min}$. The 144 instantaneous discharge measurements caused velocity fluctuations, which were smoothed 145 using a 5 min central moving average in further data preparation.

\section{3. Methods}

\section{3.1. Adaptive subcatchment discretization}

148 The proposed subcatchment discretization algorithm extends the automatic SWMM model 149 construction tool introduced by Warsta et al. (2017). They divided the investigated area into 150 subcatchments using a uniform computation grid with a desired spatial resolution. The grid 151 cells were then connected to each other and into the stormwater network. Following Krebs et 152 al. (2014), the generated subcatchments were small enough to be hypothesized to consist of a 153 single homogenous land cover type, e.g., a green area, a rooftop, or a paved road. This 
154 simplifies the calibration of the resulting SWMM model by allowing parameters to be linked

155 to distinct surface types. In the proposed algorithm, the subcatchments are still assumed to be

156 of a homogeneous land cover type, but their sizes depend on the underlying land cover and

157 flow routing. This reduces the number of subcatchments greatly in areas where land cover and

158 topography are uniform.

159 The proposed algorithm proceeds as follows:

160 1. A model with a uniform computation grid where each grid cell corresponds to one subcatchment is created for the studied area.

2. Cells with open storm sewer nodes are initially saved as a set of one-cell-sized subcatchments. SWMM parameters for each subcatchment are adopted from the node cell.

3. Subcatchments are processed one by one.

4. All adjacent upstream cells routed into the currently processed subcatchment are listed:

a. If an upstream cell has the same land cover as the currently processed subcatchment, the cell is merged to the subcatchment. Subcatchment parameters (area, elevation, slope) are updated.

b. If an upstream cell has different land cover than the currently processed subcatchment, a new subcatchment is created. Subcatchment properties are copied from the underlying cell for the newly created subcatchment. Downstream subcatchment is set as the outlet of the new subcatchment. subcatchment. Subcatchment parameters (area, elevation, slope) are computed for each 

merged roof subcatchment. Depending on the given land cover class for the roof, the roof subcatchments are routed either

a. to the nearest adjacent (non-roof) subcatchment (disconnected roof in Fig. 1) or b. directly to the nearest storm sewer node (connected roof).

182 Subcatchment cells with an open storm sewer node are connected into the stormwater network.

183 Furthermore, a $3 \times 3$ cell area surrounding each open storm sewer node is used as a collecting area for the node to account for errors in flow routing resulting from inaccuracies in the DEM. Cells not contributing to any downstream subcatchment or storm sewer node, e.g., at the borders of the study area, are disregarded from further analysis. Subcatchment area is the combined area of the contributing cells, whereas subcatchment elevation and slope are assigned 188 the average of the contributing cells. The flow width $(F W)$ parameter for adaptive subcatchments is approximated after Krebs et al. (2014) as

$$
F W=k \sqrt{A}
$$

191 where $A$ is the subcatchment area and $k=0.7$.

192 The proposed algorithm requires three raster files with equal dimensions and resolution as 193 inputs: a land cover raster where different land cover classes are identified with integers, a

194 DEM raster depicting the topography of the studied area, and a flow direction raster with integers from 1 (north-east) to 8 (north) indicating the direction of flow from each raster cell.

196 It is assumed that all cells in the flow direction raster are routed, i.e., there are no pits. Other 197 input files to the tool are identical to those reported by Warsta et al. (2017), consisting of 198 geometry files for the stormwater network, a file relating the land cover raster indices to 199 SWMM subcatchment parameters, and various settings files. Given the input files, the tool 
produces a SWMM input file (.inp) ready to be used in simulations and a set of GIS-compatible

201 files that facilitate visualization of model set-up in GIS software.

\subsection{Model implementations}

203 Two models for the Länsi-Pakila catchment were created; a model where all subcatchments are

204 rectangular and have dimensions of $1 \times 1 \mathrm{~m}^{2}$ (referred to as $1 \times 1$ ) and a model with adaptive subcatchments (adap) according to the proposed algorithm. The $1 x 1$ model acts as the reference model for assessing the subcatchment discretization impact on simulation performance.

Six largest rainfall-runoff events from the Länsi-Pakila catchment were selected for analysis (Table 2). Three of the events were used for model calibration and the remaining three were validation events. Earlier, Sillanpää and Koivusalo $(2014,2015)$ showed a difference in urban runoff response between minor and major storms due to the runoff-contributing area expanding

211 from impervious to pervious areas during major storms. Because the storm size may affect

212 model parameterization, and because the main interest was in potential urban flood-producing 213 events, the selected events were all major storms (rainfall accumulation $>17 \mathrm{~mm}$ ). The

214 threshold defining a major storm corresponds with the rainfall threshold set by Sillanpää and 215 Koivusalo (2014) and Guan et al. (2016) for similar climate and catchment conditions.

217 Land cover in both $1 x 1$ and adap was represented with 6 classes. All model parameter values except for infiltration parameters corresponded to those used by Warsta et al. (2017) and Krebs et al. (2014) for similar urban catchments in Finland (Appendix A). Initial tests showed SWMM to be sensitive to the Green-Ampt infiltration model parameters, i.e., the suction head $\left(\psi_{s}\right)$, the saturated hydraulic conductivity $\left(K_{s}\right)$, and the maximum soil moisture deficit $\left(\theta_{d \max }\right)$, 
223 of the underlying soil were uniform for all land cover types and PEST (v.13) software (Doherty, 224 2016) with Tikhonov regularization was used to calibrate the adap model. The parameters for 225 loamy sand from Rawls et al. (1992) were used as initial values. The calibration was conducted 226 by minimizing the sum of squared errors of simulated flow against observed flow for time steps 227 when observed flow exceeded a threshold of $7-15 \mathrm{l} / \mathrm{s}$ depending on the event. The threshold 228 was selected due to the focus on potential flood-producing events and the desire to match peak 229 flows rather than base flow. The same calibrated parameters were then used for the $1 x 1$ model.

230 The flow direction raster was created from the DEM. As a pre-processing step, the stormwater 231 network information was integrated into the DEM using "stream burning" (e.g., Saunders, 232 1999) to ensure maximum collecting area for the catchment. Subsequently, the original DEM 233 without network burning from the corresponding area was used to produce the flow direction 234 raster using r.watershed tool from GRASS GIS (GRASS Development Team, 2017). Cells with 235 land cover classified as buildings were set to block the overland flow and cells with open storm 236 sewer nodes were set to collect the water.

237 The model performance was evaluated against observations using the Nash-Sutcliffe efficiency 238 NSE (-) (Nash and Sutcliffe, 1970), volume error (relative bias) VE (\%), and peak flow error 239 PFE (\%).

$$
V E=100 \frac{V_{S}-V_{o}}{V_{o}}
$$

$$
P F E=100 \frac{Q_{s, \max }-Q_{o, \max }}{Q_{o, \max }}
$$


where $Q_{o, t}$ and $Q_{s, t}$ are the observed and simulated discharge (1/s), respectively, at time $t, \overline{Q_{o}}$

244 is the average observed discharge (1/s) during an event, $V_{o}$ and $V_{s}$ are the observed and simulated

245 flow volumes $\left(\mathrm{m}^{3}\right)$, respectively, during an event, and $Q_{o, \max }$ and $Q_{s, \max }$ are the observed and simulated maximum discharges (1/s), respectively. The performance of adap was evaluated against $1 x l$ using the Pearson correlation coefficient $r(-)$ :

$$
r=\frac{\sum_{t}\left(Q_{1, t}-\overline{Q_{1}}\right)\left(Q_{a, t}-\overline{Q_{a}}\right)}{\sqrt{\sum_{t}\left(Q_{1, t}-\overline{Q_{1}}\right)^{2}} \sqrt{\sum_{t}\left(Q_{a, t}-\overline{Q_{a}}\right)^{2}}}
$$

where $Q_{1, t}$ and $Q_{a, t}$ are the simulated discharges (1/s) at time $t$ from the $1 x 1$ and the adap models, respectively, and $\overline{Q_{1}}$ and $\overline{Q_{a}}$ are the average simulated discharges (1/s) during an event using the $1 x 1$ and the adap models, respectively. In addition, the performance was evaluated using volume difference $V D(\%)$ and the peak flow difference PFD (\%) by substituting $1 x 1$ and adap for observed and simulated in Eqs. (3) and (4), respectively.

\section{Results}

\subsection{Adaptive subcatchment discretization}

Table 3 presents the subcatchment statistics for adap and $1 x 1$ subcatchment discretizations. The adap model resulted in only $10 \%$ (82 554) of the number of uniform $1 \times 1 \mathrm{~m}^{2}$ subcatchments in $1 x 1$ (848 258). The subcatchment sizes for adap ranged up to $9322 \mathrm{~m}^{2}$ with a mean size of $10.3 \mathrm{~m}^{2}$. As both adap and $1 x 1$ share the same input DEM data, the mean subcatchment elevation and slope are equal. Differences in the range of subcatchment

261 elevations and slopes are due to some individual raster cell subcatchments of $1 x 1$ being merged

262 in adap. The maximum subcatchment slope of over $400 \%$ is explained by local errors in the

263 DEM. For $1 x 1$, with all the subcatchments having constant dimensions of $1 \times 1 \mathrm{~m}^{2}$, the 
265 perpendicular or diagonal from the cell. For adap subcatchments, the flow width was computed 266 using Eq. (1) resulting in a larger range of flow widths for individual subcatchments. The

267 average subcatchment flow width was however similar for both models; 0.9 and $1.4 \mathrm{~m}$ for $1 x 1$ 268 and adap, respectively.

270 Creating the adap models using the proposed algorithm consumed $30 \%$ more time (29.3 min) 271 than creating the $1 x 1$ model $(22.6 \mathrm{~min})$. The reduction in the number of subcatchments led to 272 a corresponding reduction in SWMM computation time; the average computation time of an 273 adap SWMM model was $10 \%$ of the corresponding $1 x 1$ model computation time for the 274 calibration and validation events (Fig. 2).

276 Fig. 3 shows the reduction in the number of subcatchments and the effect of combining 277 individual cells into larger subcatchments on flow routes when moving from $1 x 1$ to adap. The 278 routing from one land cover type to another follows the same paths in adap and in $1 x 1$. 279 However, in adap the number of subcatchments is substantially lower as cells with the same 280 land cover type and sharing a common flow path have been merged. Note that the flow routing

281 in Fig. 3 is displayed between subcatchment mass centers, creating an illusion that not all adap 282 subcatchments are routed when in fact some subcatchment mass centers are situated outside 283 the subcatchment and/or the figure. 


\subsection{Model calibration and validation}

286 Fig. 4 illustrates the adap and $1 x 1$ simulation results for the calibration and validation events,

287 while Table 4 presents the corresponding performance statistics (Eqs. 2 - 5). The adap model

288 performed well for both calibration and validation events. For all events except v1, NSE

289 coefficients exceeded 0.90 indicating "very good" adap model performance, and NSE of 0.8

290 for event v1 still indicated "good" model performance according to the recommended model-

291 performance classes by Ritter and Muñoz-Carpena (2013). Regardless of the event, simulations

292 from adap tended to slightly underestimate flow volumes with the underestimate somewhat

293 larger for the validation events (average $V E-13.1 \%$ ) than for the calibration events $(-7.1 \%)$.

294 This was partly explained by a more rapid return to pre-storm flow levels in the simulations

295 than in the observed data, although some of the high flows were also underestimated. Peak

296 levels were mainly well captured, with $P F E$ less than $10 \%$ except for events c3 (PFE -11.3\%)

297 and v3 (19.3\%). Only for event v3 did adap overestimate the peak flow.

[FIGURE 4]

[TABLE 4]

300 Performance of the $1 x 1$ model in terms of NSE varied from "acceptable" for events v1 and c1 to "very good" for c2 and c3 (Table 4). Unlike in adap simulations where volume error was negative for all events, in $1 x 1$ the flow volume was overestimated for all events with $V E$ ranging from $5.1 \%$ for $\mathrm{v} 1$ to $22.9 \%$ for $\mathrm{c} 1$. For events $\mathrm{c} 1$ and $\mathrm{v} 3,1 \times 1$ overestimated the peak flow by roughly $20 \%$. However, for the other events the peak flow was accurately simulated.

305 The statistics between adap and $1 x 1$ (Table 4) highlight the similar reaction of both models to

306 rainfall events, as demonstrated by the correlation coefficients between adap and 1xl 307 approaching unity. Still, adap constantly produced $15-25 \%$ lower flow volumes than $1 x 1$. 
308 Although in absolute terms $V E$ of both models was similar, adap on average underestimated

309 observed flow volumes by $10.1 \%$ while $1 x 1$ overestimated by $11.6 \%$. The adap model

310 generally predicted roughly $5 \%$ lower peak flows than $1 x 1$ with the maximum PFD being

$311-17.4 \%$ for event $\mathrm{c} 1$. For this event, the difference was almost entirely due to discharge

312 overestimation of $1 \times 1$.

313 The differences in peak flows and flow volumes are consistent with catchment mass balance

314 differences between adap and $1 x 1$ (Table 5). In each event, share of surface runoff was less for

315 adap than for $1 x 1$, whereas infiltration was greater for adap than for $1 x 1$. In addition, adap

316 produced slightly less evaporation than $1 x 1$ while final stored water volume was slightly larger

317 in adap than in $1 \times 1$.

[TABLE 5]

\section{5. Discussion}

320 Automated DEM-based methods for SWMM subcatchment generation have been proposed

321 before, but they differ from the current algorithm. Dongquan et al. (2009) aimed for a low number of computational units by using a high-resolution $2 \times 2 \mathrm{~m}^{2}$ DEM but combining all cells belonging to the same drainage basin into subcatchments regardless of land cover or flow

324 routing details. Their approach resulted in 113 subcatchments for a 13.65 ha study area, 325 yielding a hundred times coarser average subcatchment size of $1200 \mathrm{~m}^{2}$ than in the adap model 326 here $\left(10.3 \mathrm{~m}^{2}\right)$. Warsta et al. (2017) described the catchments in fine detail but because each cell was considered an individual subcatchment, computation times were long with a large number of redundant cells in areas with a homogenous land cover type. This is analogous to the $1 x 1$ simulations here. In the proposed adaptive algorithm, more subcatchments are generated in areas where either land cover or flow routes are heterogeneous whereas in more 
331 homogenous areas the subcatchments are allowed to have a larger size. The rudimentary grid 332 cell aggregation procedure of Warsta et al. (2017) yielded shorter computation times, but 333 changed the land cover and flow routing patterns in the catchment. This resulted in a moderate 334 reduction of simulated peak flows and flow volumes. Here, the computation time was greatly 335 reduced as adap simulations took on average only $10 \%$ of the corresponding $1 x 1$ simulation 336 time, while both adap and $1 x 1$ produced good simulation results. The smaller computational 337 burden associated with the proposed algorithm allows model construction for large urban 338 catchments.

339 Because no manually constructed SWMM models exist for the studied catchment, direct 340 comparison of computation times to a corresponding manual model was not possible. However, 341 a crude estimate of a roughly five-fold increase in computation time between a manual model 342 and a corresponding adap model was approximated by comparing models from earlier studies. 343 In the work of Niemi et al. (2019), the proposed algorithm was used to create SWMM models 344 with adaptive subcatchments for three small urban catchments $(5.87,6.63$, and 12.59 ha 345 catchment areas) in Lahti, Finland. Earlier, Krebs et al. (2014) manually constructed high346 resolution SWMM models for the same catchments. The adap models in Lahti had, on average,

34714.7 times the number of subcatchments when compared to the corresponding manual models, 348 and required, on average, 4.8 times as long to compute.

349 The adaptive subcatchment discretization algorithm retains the high spatial resolution of the input DEM and land cover data where necessary, but creates larger subcatchments where such spatial detail is not crucial. This allows for an accurate spatial representation of land cover,

352 deemed important by Cantone and Schmidt (2009) and Petrucci and Bonhomme (2014).

353 However, it also relieves the computational burden that can become excessive with a uniformly 354 high spatial resolution model. Given that input land cover data are in raster format, the 
355 developed algorithm retains the land cover description from the input data. Otherwise, the accuracy of the land cover description depends on the rasterization of non-raster-format input data.

When building stormwater models manually, surfaces are usually assumed to drain entirely into a single inlet node unless there is a compelling reason to resolve the routing in other way. Therefore, an entire impervious surface, such as a parking lot, may be routed into a single inlet although actual topography-driven flow paths would drain a part of the area to adjacent yards. In the method of Warsta et al. (2017), routing of pit cells depended on their location in either pervious or impervious areas. All water routed into pits residing in pervious areas was infiltrated whereas water routed into pits in impervious areas was routed directly to the nearest storm sewer node. As a result, some areas did not contribute to the catchment runoff as the water had been infiltrated into a pit along its flow path. On the other hand, contribution of other areas was unduly exaggerated as flow from them was routed directly to the stormwater network. The proposed new algorithm allows the water to follow topography-driven flow paths, and the use of a depressionless DEM ensures that water is routed through local pits. This refined routing, compared to Warsta et al. (2017), should offer better runoff predictions during major storms when pervious surfaces get saturated and start to convey runoff (Sillanpää and Koivusalo, 2014; Yao et al., 2016).

373 Both adap and $1 x 1$ models appropriately reproduced the observed runoff at the studied catchment. The slight underestimation of flow volumes by adap was expected, as the underestimation by SWMM in simulating hydrograph tails and low flows is commonly encountered (e.g., Guan et al., 2015, 2016). This behaviour was accentuated by calibration of adap focusing on high flows in lieu of low flows to more accurately simulate potential urban flood-producing events. 
379 Because the model parameters in adap and $1 x 1$ were identical, differences in simulated flow

380 volumes and peak flows between the implementations are explained by those model

381 characteristics that were different: flow width, subcatchment slope, and subcatchment area. As

382 these variables appear in the Manning equation SWMM uses to express the surface runoff for

383 each computation time step, the dynamics of runoff production are altered when the parameters

384 change. More importantly, the volume of infiltrated water within a subcatchment depends on

385 its size. As the volume of the infiltrated water is the product of the area and infiltration depth,

386 a larger subcatchment can infiltrate more water than an equally parameterized but a smaller

387 subcatchment. In adap, the average subcatchment size was larger than in $1 x 1$ and the likelihood

388 of runon being completely or mostly infiltrated was larger. It is noteworthy, that the

389 dependence of infiltration volume on subcatchment size involves all SWMM models,

390 regardless of their construction procedure. The matter concerns especially models that treat

391 infiltration as a loss from the system without consideration of the storage capacity of the

392 underlying ground.

393 Adjusting only the infiltration parameters while taking other input parameters from Warsta et

394 al. (2017) and Krebs et al. (2014) was sufficient to yield a well-performing model, with relative

395 uncertainty variance reductions of $0.61,0.99$, and 0.96 for $\psi_{s}, K_{s}$, and $\theta_{d \max }$ respectively.

396 These results are in line with earlier research suggesting that extensive calibration of a

397 hydrological model may be unnecessary if representative parameter sets are available from

398 similar catchments (Bárdossy, 2007; Gao et al., 2015; Kokkonen et al., 2003; Krebs et al.,

399 2016). The results also support the findings of Petrucci and Bonhomme (2014) stating that an

400 uncalibrated SWMM model may perform comparably to a calibrated model as long as land

401 cover is described accurately. The slightly less accurate discharge simulations from $1 x 1$ than

402 adap were because infiltration parameters were calibrated using adap and applied to $1 x 1$ 
without further calibration. However, had $1 x 1$ also been calibrated the differences between the models would likely be smaller.

SWMM performance is often found to be sensitive to the subcatchment flow width parameter (Niazi et al., 2017). Here, the sensitivity to $F W$ was assessed by evaluating the performance of adap in event $\mathrm{c} 1$ with calibrated infiltration parameter values while allowing coefficient $k$ in

$408 F W$ (Eq. 1) to vary from 0.3 to 1.1 in steps of 0.2 . The results showed adap to be rather insensitive to $F W$ (NSE variation between $0.91-0.94, P F E-1.36 \%-1.43 \%$, and $V E-3.99 \%$ $--4.44 \%$ ), justifying the decision to use Eq. (1) with $k=0.7$ to describe the flow width in this

411 study. However, due to the often encountered importance of proper flow width

412 parameterization in SWMM modelling, and the possibility to calculate it explicitly in the 413 proposed algorithm that traverses through raster cells, this should be considered as one of the 414 first improvements to the presented algorithm.

\section{6. Conclusions}

416 This study presented a new algorithm for automating SWMM model construction with a novel 417 solution to delineate subcatchments based on shared land cover and outlet. The algorithm 418 creates subcatchments adaptively by merging small subcatchments having homogeneous land 419 cover and common outlet into larger areas while retaining small-scale details where land cover 420 is heterogeneous. While pre-processing the input files for the proposed tool is convenient to 421 perform in a GIS software, the proposed tool itself is platform-independent, open-source, and 422 not tied to any specific GIS software. The tool facilitates urban hydrological assessments by substantially reducing the required manual workload.

424 Based on the results obtained in this study, the following conclusions were drawn: 
- The proposed algorithm facilitates rapid model construction even for large urban areas while retaining the high-resolution details where necessary.

- SWMM simulation results obtained using the proposed algorithm matched well with catchment discharge observations.

- Use of adaptive subcatchments resulted in a substantial reduction in the computational

\section{Appendix A}

Table A1 presents the land cover parameter values used in adap and $1 x 1$ adopted from Warsta et al. (2017) and Krebs et al. (2014) for similar urban catchments in Finland. The Green-Ampt infiltration parameters are based on model calibration.

\section{Acknowledgements}

443 This research is a part of the EU WaterJPI project 'Multi-scale urban flood forecasting' 444 (MUFFIN). The funding was provided by Maa- ja vesitekniikan tuki ry. The tool is available 445 from GitHub (https://github.com/AaltoUrbanWater/GisToSWMM5). Luode Consulting Oy is 446 acknowledged for the discharge measurements. The City of Helsinki and the Helsinki Region 447 Environmental Services Authority HSY are acknowledged for the DEM and the land cover 
448 data (available from https://kartta.hel.fi), and for the stormwater network information. The 449 temperature data from the Kumpula weather station of the Finnish Meteorological Institute are 450 available from https://en.ilmatieteenlaitos.fi/open-data. Helsingin Seniorisäätiö and the City of 451 Helsinki are acknowledged for allowing rainfall measurements on their premises. Thanks are 452 due to Lassi Warsta for sharing his ideas about automated SWMM construction and to Ambika 453 Khadka for discussions regarding stormwater modelling.

\section{References}

455

456

457

458

459

460

461

462

463

464

465

466

467

468

Bárdossy, A. (2007). "Calibration of hydrological model parameters for ungauged catchments." Hydrol. Earth Syst. Sci. 11, 703-710.

Bates, P.D. (2012). "Integrating remote sensing data with flood inundation models: how far have we got?" Hydrol. Process. 26, 2515-2521.

Bates, P.D. (2004). "Remote sensing and flood inundation modelling." Hydrol. Process. 18, $2593-2597$.

Bengtsson, L., and Semádeni-Davies, A. (2011). "Urban Snow", in: Singh, V.P., Singh, P., Haritashya, U.K. (eds.), Encyclopedia of Snow, Ice and Glaciers. Springer, Dordrecht, Netherlands, pp. 1211-1217.

Cantone, J.P., and Schmidt, A.R. (2009). "Potential Dangers of Simplifying Combined Sewer Hydrologic/Hydraulic Models.” J. Hydrol. Eng. 10.1061/(ASCE)HE.1943-5584.0000023, 596-605.

Doherty, J. (2016). PEST: Model-Independent Parameter Estimation (User Manual, Part 1). Watermark Numerical Computing, Brisbane, Australia. 
469 Dongquan, Z., Jining, C., Haozheng, W., Qingyuan, T., Shangbing, and C., Zheng, S. (2009).

470 "GIS-based urban rainfall-runoff modeling using an automatic catchment-discretization 471 approach: a case study in Macau." Environ. Earth Sci. 59.

472 Elliott, A.H., Trowsdale, S.A., and Wadhwa, S. (2009). "Effect of Aggregation of On-Site 473 Storm-Water Control Devices in an Urban Catchment Model." J. Hydrol. Eng. 474 10.1061/(ASCE)HE.1943-5584.0000064, 975-983.

475 Fletcher, T.D., Andrieu, H., and Hamel, P. (2013). "Understanding, management and 476 modelling of urban hydrology and its consequences for receiving waters: A state of the art." $477 \quad$ Adv. Water Resour. 51, 261-279.

478 French, J.R. (2003). "Airborne LiDAR in support of geomorphological and hydraulic 479 modelling." Earth Surf. Process. Landf. 28, 321-335.

480 Gao, W., Guo, H.C., and Liu, Y. (2015). "Impact of Calibration Objective on Hydrological 481 Model Performance in Ungauged Watersheds." J. Hydrol. Eng. 10.1061/(ASCE)HE.1943$482 \quad 5584.0001116 .04014086$.

483 Ghosh, I., and Hellweger, F.L. (2012). "Effects of Spatial Resolution in Urban Hydrologic 484 Simulations.” J. Hydrol. Eng. 10.1061/(ASCE)HE.1943-5584.0000405. 129-137.

485 Gironás, J., Niemann, J.D., Roesner, L.A., Rodriguez, F., and Andrieu, H. (2010). “Evaluation 486 of Methods for Representing Urban Terrain in Storm-Water Modeling." J. Hydrol. Eng. 487 10.1061/(ASCE)HE.1943-5584.0000142. 1-14.

488 Goldstein, A., Foti, R., and Montalto, F. (2016). "Effect of Spatial Resolution in Modeling 489 Stormwater Runoff for an Urban Block.” J. Hydrol. Eng. 10.1061/(ASCE)HE.1943$490 \quad 5584.0001377,06016009$. 
Guan, M., Sillanpää, N., and Koivusalo, H. (2016). "Storm runoff response to rainfall pattern, magnitude and urbanization in a developing urban catchment." Hydrol. Process. 30, 543-557. changes in a developing urban catchment." Hydrol. Process. 29, 2880-2894. Jacobson, C.R. (2011). "Identification and quantification of the hydrological impacts of imperviousness in urban catchments: A review.” J. Environ. Manage. 92, 1438-1448.

Kertesz, R., Heaney, J., and Sansalone, J. (2007). "Disaggregated Modeling for Urban

500 Hydrologic Controls", Proc., World Environmental and Water Resources Congress 2007:

Kokkonen, T.S., Jakeman, A.J., Young, P.C., and Koivusalo, H.J. (2003). "Predicting daily flows in ungauged catchments: model regionalization from catchment descriptors at the

504 Coweeta Hydrologic Laboratory, North Carolina.” Hydrol. Process. 17, 2219-2238.

505 Kong, F., Ban, Y., Yin, H., James, P., and Dronova, I. (2017). "Modeling stormwater 506 management at the city district level in response to changes in land use and low impact 507 development." Environ. Model. Softw. 95, 132-142.

508 Krebs, G., Kokkonen, T., Setälä, H., and Koivusalo, H. (2016). "Parameterization of a 509 Hydrological Model for a Large, Ungauged Urban Catchment.” Water 8, 443.

510 Krebs, G., Kokkonen, T., Valtanen, M., Koivusalo, H., and Setälä, H. (2013). “A high 511 resolution application of a stormwater management model (SWMM) using genetic parameter 512 optimization." Urban Water J. 10(6), 394-410. 
513 Krebs, G., Kokkonen, T., Valtanen, M., Setälä, H., and Koivusalo, H. (2014). "Spatial

514 resolution considerations for urban hydrological modelling.” J. Hydrol. 512, 482-497.

515 Mejía, A.I. and Moglen, G.E. (2010). "Impact of the spatial distribution of imperviousness on

516 the hydrologic response of an urbanizing basin." Hydrol. Process. 24, 3359-3373.

517 Nash, J.E., and Sutcliffe, J.V. (1970). "River flow forecasting through conceptual models part

518 I - A discussion of principles.” J. Hydrol. 10, 282-290.

519 Niazi, M., Nietch, C., Maghrebi, M., Jackson, N., Bennett, B. R., Tryby, M., and Massoudieh,

520 A. (2017). "Storm Water Management Model: Performance Review and Gap Analysis." 521 Journal of Sustainable Water in the Built Environment, 10.1061/JSWBAY.0000817. 04017002

522 Niemi T.J., Krebs G., and Kokkonen T. (2019). “Automated Approach for Rainfall-Runoff 523 Model Generation.” In: Mannina G. (Ed.) New Trends in Urban Drainage Modelling. UDM 524 2018. Green Energy and Technology. Springer, Cham. 597-602.

525 Niemi, T.J., Warsta, L., Taka, M., Hickman, B., Pulkkinen, S., Krebs, G., Moisseev, D.N., 526 Koivusalo, H., and Kokkonen, T. (2017). "Applicability of open rainfall data to event-scale 527 urban rainfall-runoff modelling." J. Hydrol. 547, 143-155.

528 Park, S.Y., Lee, K.W., Park, I.H., and Ha, S.R. (2008). "Effect of the aggregation level of 529 surface runoff fields and sewer network for a SWMM simulation.” Desalination 226, 328-337.

530 Pauleit, S., Ennos, R., and Golding, Y. (2005). "Modeling the environmental impacts of urban 531 land use and land cover change — a study in Merseyside, UK.” Landsc. Urban Plan. 71, 295532310. 
533 Peleg, N., Blumensaat, F., Molnar, P., Fatichi, S., and Burlando, P. (2017). "Partitioning the 534 impacts of spatial and climatological rainfall variability in urban drainage modeling." Hydrol. 535 Earth Syst. Sci. 21, 1559-1572.

536 Petrucci, G. and Bonhomme, C. (2014). "The dilemma of spatial representation for urban 537 hydrology semi-distributed modelling: Trade-offs among complexity, calibration and 538 geographical data.” J. Hydrol. 517, 997-1007.

539 Pina, R.D., Simões, N.E., Sá Marques, A., and Sousa, J. (2011). "Floodplain delineation with 540 Free and Open Source Software". Proc., 12th Int. Conf. on Urban Drainage. 12-15 September 2011, Porto Alegre, Brazil.

542 Pirinen, P., Simola, H., Aalto, J., Kaukoranta, J.-P., Karlsson, P., and Ruuhela, R. (2012).

543 Climatological statistics of Finland 1981-2010. Finnish Meteorological Institute, Helsinki.

544 http://hdl.handle.net/10138/35880

545 Raukola, P. (2012). Hulevesitulvariskien alustava arviointi Helsingin kaupungissa 546 (Preliminary stormwater flood risk assessment in the city of Helsinki), MSc. Thesis. Tampere 547 University of Technology, Tampere, Finland. (In Finnish). http://URN.fi/URN:NBN:fi:tty201211121345

Rautiainen, M. (2016). Hulevesimallinnus ja tulvariskin arviointi Turun sataman valumaalueella (Storm water modelling and flood risk assessment in Turku harbor catchment), MSc. Thesis. Aalto University, Espoo, Finland. (In Finnish). http://urn.fi/URN:NBN:fi:aalto201611025308

553 Rawls, W.J., Ahuja, L.R., Brakensiek, D.L., and Shirmohammadi, A. (1992). "Infiltration and 554 soil water movement”, in: Maidment, D.R. (Ed.), Handbook of Hydrology. McGraw-Hill Inc., 555 New York, pp. 5.1-5.51. 
556 Ritter, A. and Muñoz-Carpena, R. (2013). "Performance evaluation of hydrological models:

557 Statistical significance for reducing subjectivity in goodness-of-fit assessments." J. Hydrol. $558 \quad 480,33-45$.

Rodriguez, F., Bocher, E., and Chancibault, K. (2013). "Terrain representation impact on

560 periurban catchment morphological properties.” J. Hydrol. 485, 54-67.

561 Rossman, L.A. (2015). Storm Water Management Model, User's Manual, Version 5.1 (No.

562 EPA/600/R-05/040). U.S. Environmental Protection Agency, Cincinnati, OH, USA.

563 Salvadore, E., Bronders, J., and Batelaan, O. (2015). "Hydrological modelling of urbanized

564 catchments: A review and future directions." J. Hydrol. 529, 62-81.

565 Sampson, C.C., Fewtrell, T.J., Duncan, A., Shaad, K., Horritt, M.S., and Bates, P.D. (2012).

566 "Use of terrestrial laser scanning data to drive decimetric resolution urban inundation models."

567 Adv. Water Resour. 41, 1-17.

568 Saunders, W. (1999). "Preparation of DEMs for use in environmental modeling analysis." 569 Proc., 1999 ESRI User Conference, ESRI, San Diego, California.

570 Shuster, W.D., Bonta, J., Thurston, H., Warnemuende, E., and Smith, D.R. (2005). "Impacts 571 of impervious surface on watershed hydrology: A review." Urban Water J. 2, 263-275.

572 Sillanpää, N. and Koivusalo, H. (2015). "Impacts of urban development on runoff event 573 characteristics and unit hydrographs across warm and cold seasons in high latitudes." J. Hydrol. $574521,328-340$.

575 Sillanpää, N. and Koivusalo, H. (2014). "Impacts of Urbanisation and Event Magnitude on 576 Runoff Contributing Area and Runoff Coefficients ”, Proc., 13th Int. Conf. on Urban Drainage 577 (ICUD 2014), 7-12 September 2014, Sarawak, Malaysia. 
578 Sun, N., Hall, M., Hong, B., and Zahn, L. (2014). "Impact of SWMM Catchment 579 Discretization: Case Study in Syracuse, New York." J. Hydrol. Eng. 10.1061/(ASCE)HE.1943-5584.0000777. 223-234.

Taka, M., Kokkonen, T., Kuoppamäki, K., Niemi, T., Sillanpää, N., Valtanen, M., Warsta, L., and Setälä, H. (2017). “Spatio-temporal patterns of major ions in urban stormwater under cold climate." Hydrol. Process. 31, 1564-1577.

Tarolli, M., Borga, M., Zoccatelli, D., Bernhofer, C., Jatho, N., and Janabi, F. al (2013). "Rainfall Space-Time Organization and Orographic Control on Flash Flood Response: The Weisseritz Event of August 13, 2002." J. Hydrol. Eng. 10.1061/(ASCE)HE.19435584.0000569. 183-193.

Tuomela, C., Jato-Espino, D., Sillanpää, N., and Koivusalo, H. (2019). “Modelling Stormwater Pollutant Reduction with LID Scenarios in SWMM", In: Mannina G. (Ed.) New Trends in Urban Drainage Modelling. UDM 2018. Green Energy and Technology. Springer, Cham. 96101.

592 Warsta, L., Niemi, T.J., Taka, M., Krebs, G., Haahti, K., Koivusalo, H., and Kokkonen, T. 593 (2017). "Development and application of an automated subcatchment generator for SWMM using open data." Urban Water J. 14, 954-963.

595 Whitford, V., Ennos, A.R., and Handley, J.F. (2001). "“City form and natural process”596 indicators for the ecological performance of urban areas and their application to Merseyside, 597 UK." Landsc. Urban Plan. 57, 91-103.

598 Yao, L., Wei, W., and Chen, L. (2016). "How does imperviousness impact the urban rainfall599 runoff process under various storm cases?” Ecol. Indic. 60, 893-905. 
600 Zhou, W., Huang, G., and Cadenasso, M.L. (2011). "Does spatial configuration matter?

601 Understanding the effects of land cover pattern on land surface temperature in urban 602 landscapes." Landsc. Urban Plan. 102, 54-63. 
604 Table 1. Land cover fractions (\%) in the Länsi-Pakila catchment.

\begin{tabular}{lc}
\hline Land cover & Fraction $(\%)$ \\
\hline Vegetation & 53.50 \\
Asphalt & 27.51 \\
Connected roofs & 7.87 \\
Disconnected roofs & 5.66 \\
Sand and gravel & 5.17 \\
Water & 0.23 \\
Rock outcrops & 0.06 \\
\hline
\end{tabular}

605

606 Table 2. Summary statistics of the studied rainfall-runoff events. Events c1-c3 were calibration 607 and v1-v3 validation events.

\begin{tabular}{lllllll}
\hline $\begin{array}{l}\text { Event } \\
\text { code }\end{array}$ & Date & $\begin{array}{l}\text { Event } \\
\text { duration } \\
(\mathrm{h})\end{array}$ & $\begin{array}{l}\text { Rainfall } \\
\text { depth } \\
(\mathrm{mm})\end{array}$ & $\begin{array}{l}\text { Peak rain } \\
\text { intensity } \\
(\mathrm{mm} / \mathrm{min})\end{array}$ & $\begin{array}{l}\text { Flow } \\
\text { volume } \\
\left(\mathrm{m}^{3}\right)\end{array}$ & Peak flow \\
\hline c1 & 6 Jun 2017 & 20 & 30.0 & 0.6 & 4321 & 540 \\
c2 & 2 Aug 2017 & 9 & 17.6 & 0.4 & 2567 & 368 \\
c3 & 9 Sep 2017 & 13 & 19.8 & 0.4 & 2882 & 364 \\
v1 & 12 Jun 2017 & 19 & 23.2 & 0.2 & 3263 & 309 \\
v2 & 4 Aug 2017 & 13 & 31.4 & 1.0 & 5368 & 509 \\
v3 & 12 Sep 2017 & 7 & 23.6 & 1.0 & 4035 & 615 \\
\hline
\end{tabular}

608

609 Table 3. Subcatchment statistics in adap (82 554 subcatchments) and $1 x 1$ (848 258

610 subcatchments) SWMM models.

\begin{tabular}{|c|c|c|c|c|c|c|}
\hline \multirow[t]{2}{*}{ Statistic } & \multicolumn{3}{|c|}{ adap } & \multicolumn{3}{|c|}{$1 \times 1$} \\
\hline & $\min$ & mean & $\max$ & $\min$ & mean & $\max$ \\
\hline Area $\left(\mathrm{m}^{2}\right)$ & 1.0 & 10.3 & 9322.0 & 1.0 & 1.0 & 1.0 \\
\hline Elevation (m.a.s.1.) & 19.1 & 27.5 & 45.8 & 13.4 & 27.7 & 45.8 \\
\hline Flow width (m) & 0.7 & 1.4 & 67.6 & 0.7 & 0.9 & 1.0 \\
\hline Slope (\%) & 0.2 & 5.5 & 417.7 & 0.1 & 5.5 & 464.0 \\
\hline
\end{tabular}

611 
612 Table 4. Performance statistics of the adap and the $1 x 1$ model simulation results against

613 observations (obs) and of the adap against the $1 x 1$ model simulation results for the calibration

614 (c1-c3) and the validation (v1-v3) events.

\begin{tabular}{|c|c|c|c|c|c|c|c|c|c|}
\hline \multirow{2}{*}{ Event } & \multicolumn{3}{|c|}{ adap vs. obs } & \multicolumn{3}{|c|}{$1 x 1$ vs. obs } & \multicolumn{3}{|c|}{ adap vs. $1 x 1$} \\
\hline & NSE(-) & $V E(\%)$ & $P F E$ (\%) & NSE (-) & $V E(\%)$ & PFE (\%) & $r(-)$ & $V D(\%)$ & PFD (\%) \\
\hline $\mathrm{c} 1$ & 0.92 & -4.1 & 0.7 & 0.74 & 22.9 & 21.9 & 0.97 & -22.0 & -17.4 \\
\hline$c 2$ & 0.97 & -9.4 & -2.2 & 0.94 & 9.8 & 7.8 & 0.99 & -17.5 & -9.3 \\
\hline c3 & 0.96 & -7.7 & -11.3 & 0.97 & 8.8 & -3.4 & 0.99 & -15.2 & -8.1 \\
\hline v1 & 0.80 & -9.6 & -5.2 & 0.70 & 5.1 & -0.1 & 0.99 & -14.0 & -5.1 \\
\hline v2 & 0.92 & -16.3 & -3.5 & 0.89 & 6.2 & 0.9 & 0.97 & -21.2 & -4.3 \\
\hline v3 & 0.91 & -13.3 & 19.3 & 0.84 & 16.4 & 21.3 & 0.95 & -25.5 & -1.6 \\
\hline
\end{tabular}

615

616 
617 Table 5. Mass balance statistics of the adap and the $1 x 1$ model simulation results for the 618 calibration (c1-c3) and the validation (v1-v3) events.

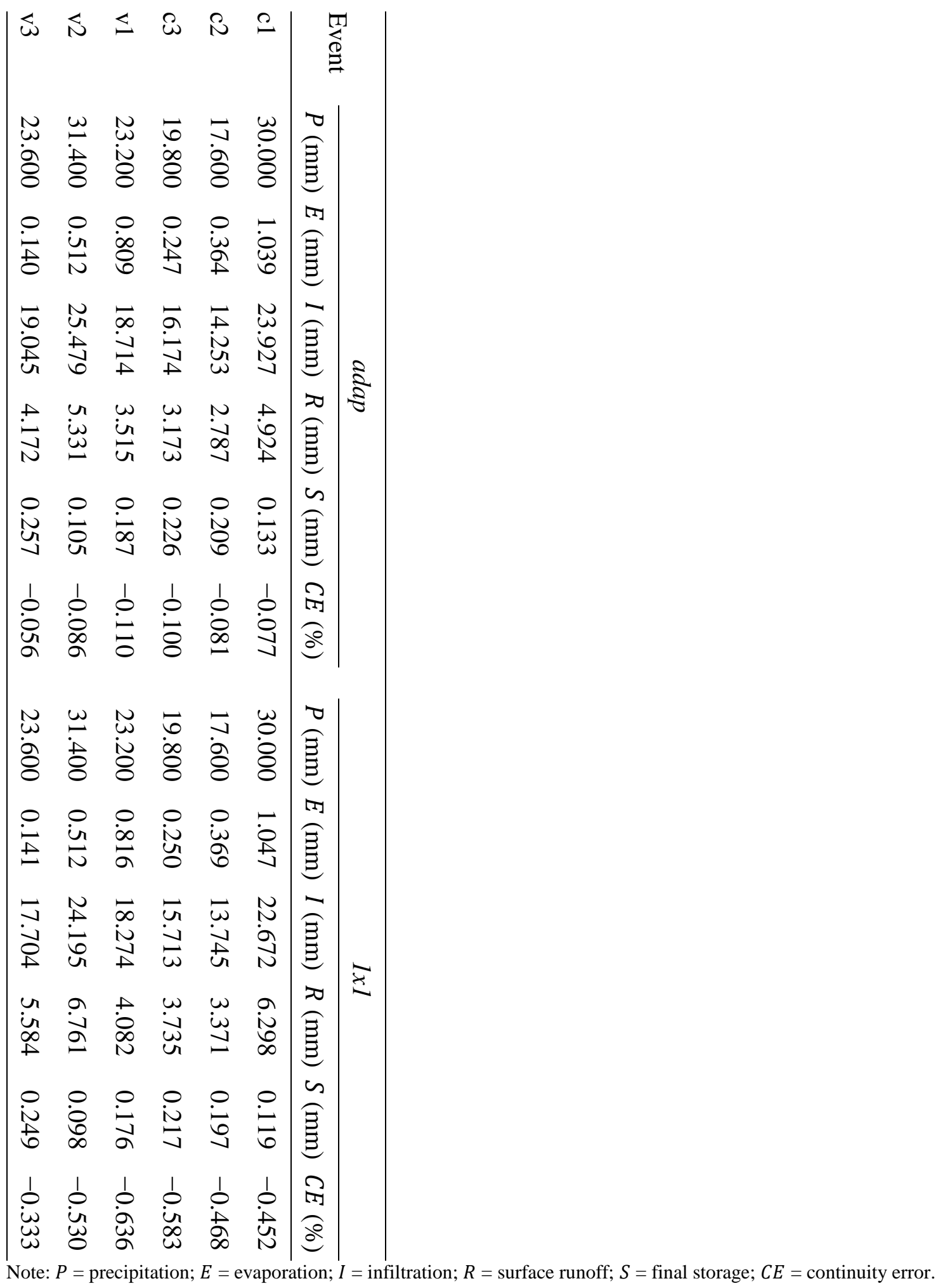


620 Table A1. SWMM parameter values for six surface classes and three stormwater network

621 classes in adap and 1x1 models. Adopted from Warsta et al. (2017) and Krebs et al. (2014).

\begin{tabular}{lrrrrrr}
\hline Surface type & $I(\%)$ & $D(\mathrm{~mm})$ & $n(-)$ & $K_{S}(\mathrm{~mm} / \mathrm{h})^{\mathrm{a}}$ & $\psi_{s}(\mathrm{~mm})^{\mathrm{a}}$ & $\theta_{\operatorname{dmax}}(-)^{\mathrm{a}}$ \\
\hline Asphalt & 100 & 0.42 & 0.011 & 24.965 & 55.832 & 0.350 \\
Rock outcrop & 100 & 2.49 & 0.030 & 24.965 & 55.832 & 0.350 \\
Roof & 100 & 0.87 & 0.012 & 24.965 & 55.832 & 0.350 \\
Sand, gravel & 33 & 2.49 & 0.030 & 24.965 & 55.832 & 0.350 \\
Vegetation & 0 & 4.22 & 0.238 & 24.965 & 55.832 & 0.350 \\
Water & 100 & 0.10 & 0.011 & 24.965 & 55.832 & 0.350 \\
Concrete pipe & - & - & 0.015 & - & - & - \\
PVC pipe & - & - & 0.011 & - & - & - \\
Open channel & - & - & 0.049 & - & - & - \\
Note: $I=$ imperviousness; $D=$ depression storage; $n=$ Manning's roughness; $K_{s}=$ saturated hydraulic conductivity; $\psi_{s}=$
\end{tabular}

622 Note: $I=$ imperviousness; $D=$ depression storage; $n=$ Manning's roughness; $K_{s}=$ saturated hydraulic conductivity; $\psi_{s}=$

623 suction head; $\theta_{d \max }=$ maximum moisture deficit; ${ }^{\mathrm{a}}$ calibrated parameter.

624 


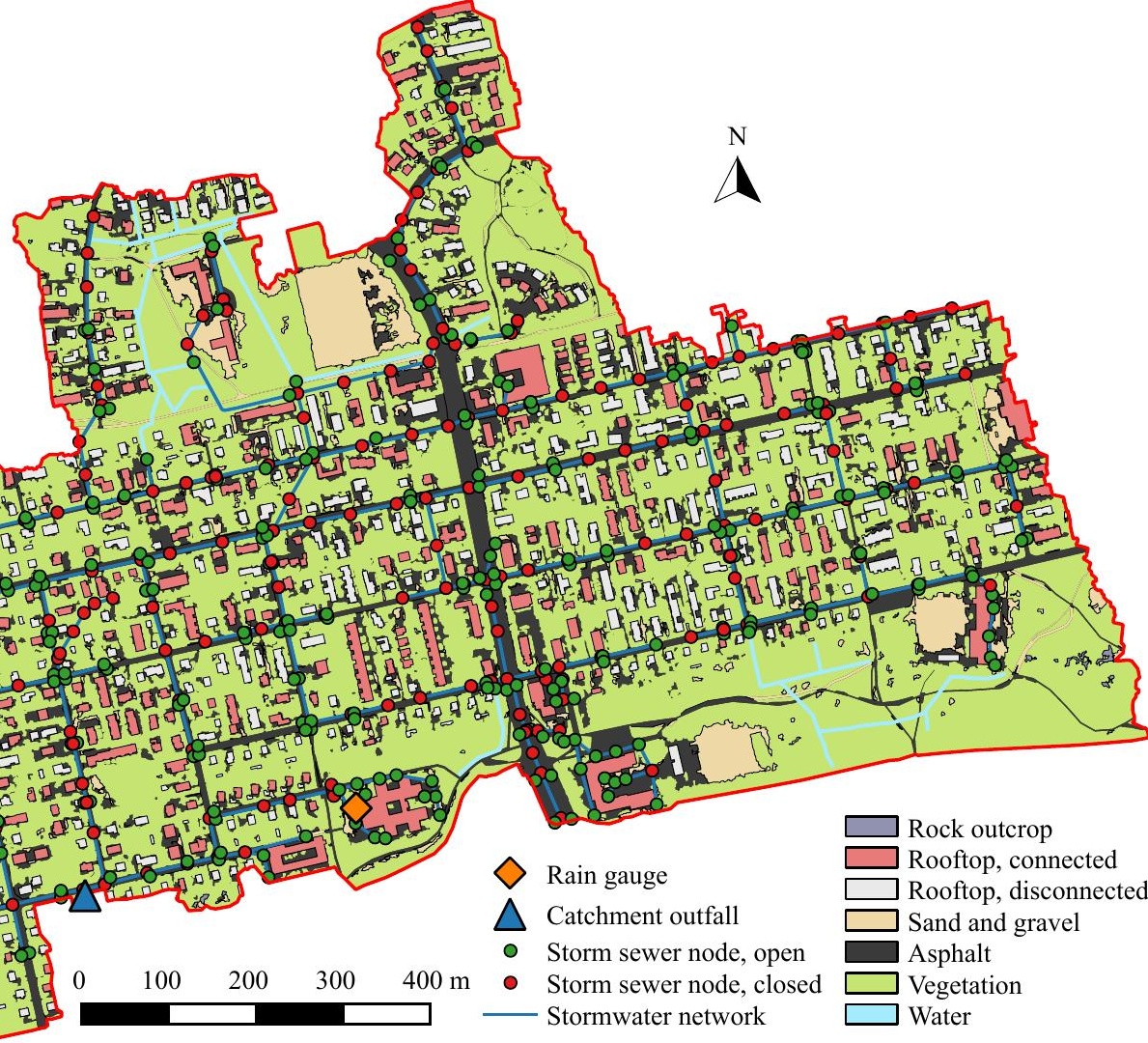




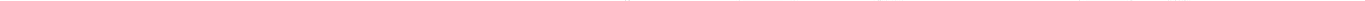


Fig. 1. Land cover and layout of the stormwater network in the Länsi-Pakila catchment. Surface runoff is routed to open storm sewer nodes, representing storm drain inlets and channel inlets, whereas runoff from connected roofs is routed both into open and closed storm sewer nodes, the latter representing manholes and pipe connections.

Fig. 2. SWMM computation times (min) for the calibration and validation events using $1 x 1$ and adap models (Desktop PC, Intel Xeon 3.20 GHz CPU, Ubuntu Linux 16.04 LTS).

Fig. 3. Comparison of subcatchments and routing between (a) $1 x 1$ and (b) adap models for the Länsi-Pakila catchment. The arrows depicting subcatchment routing are drawn between the subcatchment mass centers.

Fig. 4. Observed (5 min moving average) and adap and $1 x 1$ simulated discharges for the calibration events (a) c1, (b) c2, and (c) c3 and for the validation events (d) v1, (e) v2, and (f) v3. 